\title{
OPEN
}

\section{Author Correction: An Early Cretaceous pterosaur with an unusual mandibular crest from China and a potential novel feeding strategy}

\author{
Xiaolin Wang, Taissa Rodrigues, Shunxing Jiang, Xin Cheng \& Alexander W. A. Kellner
}

Correction to: Scientific Reports https://doi.org/10.1038/srep06329, published online 11 September 2014

This Article Wang et al. (2014), which was published electronically, does not include evidence of registration in ZooBank within the work itself, as required by Art. 8.5.3 of the amended Code of the International Commission on Zoological Nomenclature (ICZN, 1999) ${ }^{1}$. Therefore, the newly proposed genus-group name Ikrandraco and species-group name I. avatar are not available from that work. This issue is addressed with this Correction.

This publication has been registered in ZooBank with the LSID: urn:lsid:zoobank.org:pub:60C039F2-4505-44C785EA-92306D626D7B. Below, we give the ZooBank LSID numbers for each of the two new names, along with the Systematic Palaeontology section of the original article ${ }^{2}$.

Systematic Paleontology

Pterosauria Kaup, 1834

Pterodactyloidea Plieninger, 1901

Dsungaripteroidea Young, 1964

Pteranodontoidea Marsh, 1876

Ikrandraco gen. nov.

urn:lsid:zoobank.org:act:E5A43C54-E155-47D4-8515-5510A9F24B69

Type species

Ikrandraco avatar, type by monotypy.

\section{Etymology}

Ikran, from the fictional flying creature portrayed in the movie Avatar that shows a well developed dentary crest and draco, from the Latin meaning dragon.

\section{Diagnosis}

The same for the type species.

Ikrandraco avatar sp. nov.

urn:lsid:zoobank.org:act:E7C1E2F4-6D50-441B-B30C-9C6DED9C2276

\section{Etymology}

Avatar, in allusion to the homonymous science fiction movie.

\section{Holotype}

A partial skeleton including complete skull and mandible, atlas, axis, three mid-cervical vertebrae, part of the sternal plate, some ribs, partial right and left wings and part of the foot (IVPP V18199), deposited at the Institute of Vertebrate Paleontology and Paleoanthropology, Chinese Academy of Sciences in Beijing, China. 
Referred specimen

A complete skull, mandible, atlas, axis and third cervical vertebra (IVPP V18406), deposited at the Institute of Vertebrate Paleontology and Paleoanthropology, Chinese Academy of Sciences in Beijing, China.

\section{Horizon and locality}

Jiufotang Formation, Early Cretaceous (Aptian) 120 Ma. IVPP V18199 was collected in Lamadong, Jianchang and IVPP V18406 comes from Sihedang, Lingyuan, western Liaoning, China.

\section{Diagnosis}

Ikrandraco avatar can be distinguished from all other pteranodontoid pterodactyloids by the following autapomorphies: slightly arched dorsal margin of the skull above the nasoantorbital fenestrae; lateral depression on the nasal; median hook-like process on the posterior edge of the dentary crest; two well-developed pneumatic foramina piercing the lateral surface of the axis. It can further be separated from other pteranodontoids by the following combination of characters: very low skull (height over quadrates about $18.7 \%$ of skull length); strongly inclined quadrate $\left(150^{\circ}\right)$; lack of a premaxillary crest; presence of a deep, blade-like bony mandibular crest with deepest point at mid-length; and a ventral pneumatic foramen on the proximal portion of the second phalanx and third phalanges of the wing finger.

\section{References}

1. International Commission on Zoological Nomenclature (ICZN). International Code of Zoological Nomenclature 4th edn, i-xxix, 1-306 (The International Trust for Zoological Nomenclature, London, 1999).

2. Wang, X. et al. An Early Cretaceous pterosaur with an unusual mandibular crest from China and a potential novel feeding strategy. Sci. Rep. 4, 6329. https://doi.org/10.1038/srep06329 (2015).

(c) (i) Open Access This article is licensed under a Creative Commons Attribution 4.0 International License, which permits use, sharing, adaptation, distribution and reproduction in any medium or format, as long as you give appropriate credit to the original author(s) and the source, provide a link to the Creative Commons license, and indicate if changes were made. The images or other third party material in this article are included in the article's Creative Commons license, unless indicated otherwise in a credit line to the material. If material is not included in the article's Creative Commons license and your intended use is not permitted by statutory regulation or exceeds the permitted use, you will need to obtain permission directly from the copyright holder. To view a copy of this license, visit http://creativecommons.org/licenses/by/4.0/.

(c) The Author(s) 2020 